\title{
Novel Therapeutic Strategies for Refractory Ovarian Cancers: Clear Cell and Mucinous Carcinomas
}

\author{
Tadahiro Shoji ${ }^{1, * \mathbb{D}}$, Shunsuke Tatsuki ${ }^{1}$, Marina Abe ${ }^{1}$, Hidetoshi Tomabechi ${ }^{1}$, Eriko Takatori ${ }^{1}$, Yoshitaka Kaido ${ }^{1}$, \\ Takayuki Nagasawa ${ }^{1}$, Masahiro Kagabu ${ }^{1}{ }^{\mathbb{D}}$, Tsukasa Baba ${ }^{1}$ and Hiroaki Itamochi ${ }^{2}$
}

1 Department of Obstetrics and Gynecology, Iwate Medical University School of Medicine, Iwate 028-3695, Japan; 412.sailing@gmail.com (S.T.); nmrhappy@gmail.com (M.A.); bechitomabehi@gmail.com (H.T.); takatori@iwate-med.ac.jp (E.T.); kaido0428@yahoo.co.jp (Y.K.); shirokuma723@ybb.ne.jp (T.N.); m.kagabu@nifty.com (M.K.); babatsu@iwate-med.ac.jp (T.B.)

2 Department of Clinical Oncology, Iwate Medical University School of Medicine, Iwate 028-3695, Japan; itamochi@iwate-med.ac.jp

* Correspondence: tshoji@iwate-med.ac.jp; Tel.: +81-19-613-7111; Fax: +81-19-622-1900

check for updates

Citation: Shoji, T.; Tatsuki, S.; Abe, M.; Tomabechi, H.; Takatori, E.; Kaido, Y.; Nagasawa, T.; Kagabu, M.; Baba, T.; Itamochi, H. Novel Therapeutic Strategies for Refractory Ovarian Cancers: Clear Cell and Mucinous Carcinomas. Cancers 2021, 13, 6120. https://doi.org/10.3390/

cancers 13236120

Academic Editor: Simon Langdon

Received: 29 October 2021

Accepted: 30 November 2021

Published: 4 December 2021

Publisher's Note: MDPI stays neutral with regard to jurisdictional claims in published maps and institutional affiliations.

Copyright: (c) 2021 by the authors. Licensee MDPI, Basel, Switzerland. This article is an open access article distributed under the terms and conditions of the Creative Commons Attribution (CC BY) license (https:// creativecommons.org/licenses/by/ $4.0 /)$.
Simple Summary: Ovarian clear cell and mucinous carcinomas are less sensitive to chemotherapy. This can be explained by carcinogenic mechanisms and molecular biological features. Although chemotherapy with cytotoxic anticancer drugs has been evaluated by clinical studies, none have achieved better treatment outcomes than paclitaxel + carboplatin therapy. In recent years, attention has been focused on treatment with molecular target drugs and immune checkpoint inhibitors that target newly identified biomarkers, and many clinical studies on such treatments have been planned.

Abstract: Ovarian cancer has the worst prognosis among gynecological cancers. In particular, clear cell and mucinous carcinomas are less sensitive to chemotherapy. The establishment of new therapies is necessary to improve the treatment outcomes for these carcinomas. In previous clinical studies, chemotherapy with cytotoxic anticancer drugs has failed to demonstrate better treatment outcomes than paclitaxel + carboplatin therapy. In recent years, attention has been focused on treatment with molecular target drugs and immune checkpoint inhibitors that target newly identified biomarkers. The issues that need to be addressed include the most appropriate combination of therapies, identifying patients who may benefit from each therapy, and how results should be incorporated into the standard of care for ovarian clear cell and mucinous carcinomas. In this article, we have reviewed the most promising therapies for ovarian clear cell and mucinous carcinomas, which are regarded as intractable, with an emphasis on therapies currently being investigated in clinical studies.

Keywords: ovarian cancer; clear cell carcinoma; mucinous carcinoma; chemotherapy; clinical trial

\section{Introduction}

The incidence of ovarian cancer is increasing every year. It is one of the most common gynecological malignancies, ranking third after cervical and uterine cancer. In 2017, there were 22,440 estimated new diagnoses of ovarian cancer and 14,080 deaths from the disease in the USA; deaths were higher than those of endometrial and cervical cancer [1].

Epithelial ovarian cancers comprise serous, mucinous, endometrioid, and clear cell carcinomas, and they mimic tissues derived from the Müller duct. In recent years, each of these histological subtypes has been shown to have different carcinogenic mechanisms and molecular biological characteristics. The prognosis of serous ovarian carcinoma has been drastically improved by the identification of biomarkers and development of polyadenosine-diphosphate-ribose polymerase inhibitors [2-4]. Compared to the prognosis of serous carcinoma, that of clear cell and mucinous carcinomas is poor [5], a factor attributed to their resistance to chemotherapy. 
Highly atypical serous carcinoma exhibits p53 mutations and arises de novo from the superficial epithelium in a short duration. KRAS mutations are common in mucinous carcinomas and have been reported to develop according to the adenocarcinoma sequence over a relatively long period of time [6]. Clear cell and endometrioid carcinomas arise from endometriotic ovarian cysts via atypical endometriosis over a long duration $[7,8]$. Itamochi et al. have demonstrated that the cell doubling time in clear cell carcinomas is approximately twice that of serous carcinomas, suggesting that the low cell proliferative capacity of the clear cell variant is associated with its low sensitivity to chemotherapy [9]. Thus, chemotherapy must be customized to the biological characteristics of each histological type. Since clear cell and mucinous carcinomas are classified as rare tumors, it is difficult to recruit patients for clinical trials and planned studies. Notably, no standard chemotherapy has been established to date.

In this article, we discuss the biological characteristics of ovarian clear cell and mucinous carcinomas and the results of previously reported clinical studies to outline the prospects for new therapeutic strategies.

\section{Clear Cell Carcinoma}

Clear cell carcinoma accounts for approximately $10 \%$ of epithelial ovarian cancers in Europe and the United States. However, its incidence in Japan is relatively high, at approximately $25 \%$ [10]. The paclitaxel + carboplatin (TC) therapy is the gold standard chemotherapy regimen for ovarian cancers, based on clinical studies including GOG111, OV-10, GOG158, and AGO trials [11-14]. Paclitaxel stops the process of cell division and kills cancer cells by inhibiting the function of microtubules. On the other hand, carboplatin shows cytotoxicity by inhibiting DNA synthesis, causing cell death in cancer cells [15].

However, in recent years, the sensitivity of clear cell carcinoma to chemotherapy has been reported to be low; different therapeutic strategies have been proposed for each histological subtype [16]. Sugiyama et al. reported that the majority of the patients enrolled in the aforementioned studies had serous carcinoma (from $66 \%$ to $72 \%$ ) and that those with clear cell carcinoma accounted for only $2.1 \%$ to $4.9 \%$ [17]. Although TC therapy is the standard therapy for poorly and well-differentiated serous carcinomas, including undifferentiated cancers and endometrioid carcinoma, there is no scientific evidence that would necessitate similar treatment for clear cell and mucinous carcinomas. At the fourth Ovarian Consensus Conference held in Vancouver in 2010, an international consensus was reached on the need for separate clinical studies on clear cell carcinoma because each type of ovarian cancer has a different genetic/molecular profile.

\subsection{Biological Characteristics}

The most common genetic mutations in ovarian clear cell carcinoma are adenine thymine-rich interactive domain $1 \mathrm{~A}(A R I D 1 A)$ and phosphatidylinositol 4,5-bisphosphate 3-kinase catalytic subunit alpha (PIK3CA) mutations, which have been identified in approximately $50 \%$ to $60 \%$ of cases. ARID1A forms SWI/SNF (switch/sucrose nonfermentable) complexes and disrupts chromatin modeling, consequently causing abnormal expression of various genes. PIK3CA contributes to cell survival and proliferation by enhancing the activity of phosphatidylinositol 3-kinase (PI3K) to activate the AKT pathway. The mutations in ARID1A and PIK3CA are frequently known to coexist [18,19]. Moreover, abnormalities in the metabolic pathways are characteristic. Although cancer cells have been confirmed to use anaerobic glycolysis even in an aerobic environment (the Warburg effect), almost all cases of ovarian clear cell carcinoma exhibit high expression levels of hepatocyte nuclear factor (HNF) $1 \beta$, which is a main cause of the Warburg effect [20]. Generally, the sensitivity to anticancer drugs is low in hypoxic environments. Abnormalities in the metabolic pathway due to high expression levels of $H N F-1 \beta$ may be associated with the resistance of ovarian clear cell carcinomas to anticancer drugs (Table 1). 
Table 1. Summary of critical genetic changes in ovarian clear cell carcinoma.

\begin{tabular}{cccc}
\hline Gene & Pathways Affected & Type of Expression Abnormality & Frequency (\%) \\
\hline ARID1A [18] & SWI/SNF & Mutation & 62 \\
ARID1B [18] & SWI/SNF & Mutation & 10 \\
PIK3CA [18,19] & PI3K & Mutation & $35-51$ \\
PTEN [18,19] & PI3K & Mutation & $2-5$ \\
PIK3R1 [18,19] & PI3K & Mutation & $7-8$ \\
PIK3R2 [19] & PI3K & Mutation & 5 \\
KRAS [19] & MAPK & Mutation & 9 \\
ERBB2 [19] & MAPK & Mutation and amplification & 11 \\
HNF-1 $\beta[20]$ & Metabolic pathway & Methylation & $>80$ \\
\hline
\end{tabular}

Abbreviations: ARID1A, AT-rich interactive domain 1A; ARID1B, AT-rich interactive domain 1B; ; PIK3CA, phosphatidylinositol-4,5-bisphosphate 3-kinase catalytic subunit alpha; PTEN, phosphatase and tensin homolog; PIK3R1/2, phosphoinositide-3-kinase regulatory subunit 1/2; ; KRAS, KRAS proto-oncogene; ERBB2, erb-b2 receptor tyrosine kinase 2; HNF1 $\beta$, hepatocyte nuclear factor 1 homeobox B; SWI/SNF, switch/sucrose nonfermentable; PI3K, phosphatidylinositol 3-kinase; MAPK, Mitogen-Activated Protein Kinase.

Tumors with the deficient mismatch repair (dMMR) phenotype respond well to immune checkpoint blockade therapy, as these tumors express many neo-antigens associated with high mutational burden [21]. Therefore, ovarian clear cell carcinomas with ARID1A deficiency may benefit from immune checkpoint blockade therapy.

\subsection{Previous Clinical Studies for Clear Cell Carcinoma}

Table 2 summarizes the results of previous clinical studies for ovarian clear cell carcinomas.

Table 2. Previous clinical trials for ovarian clear cell carcinoma.

\begin{tabular}{|c|c|c|c|c|c|c|}
\hline Trials & Patients & $\mathbf{N}$ & Arms/Treatments & ORR & $\begin{array}{c}\text { Median PFS/ } \\
\text { 2-Year Disease-Free } \\
\text { Survival Rate }\end{array}$ & $\begin{array}{c}\text { Median OS/ } \\
\text { 2-Year Survival } \\
\text { Rate }^{* * *}\end{array}$ \\
\hline JGOG3014 [22] & $\begin{array}{l}\text { Stage I-IV } \\
\text { First-line }\end{array}$ & 99 & $\begin{array}{c}\mathrm{TC}^{*} \times 6 \\
\mathrm{CPT}-\mathrm{P} \times 6\end{array}$ & $\begin{array}{l}40 \\
25\end{array}$ & $\begin{array}{l}\text { NA } \\
\text { NA }\end{array}$ & $\begin{array}{l}\text { NA } \\
\text { NA }\end{array}$ \\
\hline JGOG3017 [23] & $\begin{array}{l}\text { Stage I-IV } \\
\text { First-line }\end{array}$ & 667 & $\begin{array}{l}\mathrm{TC}^{* *} \times 6 \\
\mathrm{CPT}-\mathrm{P} \times 6\end{array}$ & $\begin{array}{l}46.7 \\
29.4\end{array}$ & $\begin{array}{l}77.6 \% \text { *** } \\
73.0 \% * * *\end{array}$ & $\begin{array}{l}87.4 \% \text { *** } \\
85.5 \% \text { *** }\end{array}$ \\
\hline GOG268 [24] & $\begin{array}{l}\text { StageIII/IV } \\
\text { First-line }\end{array}$ & $\begin{array}{c}45 \\
\text { (Japan) } \\
45 \\
\text { (US/Korea) }\end{array}$ & $\begin{array}{c}\mathrm{TC}^{* *}+\text { Temsirolimus } 25 \\
\text { mg/body } \times 6 \\
\rightarrow \text { Temsirolimus } 25 \\
\text { mg/body }\end{array}$ & $\begin{array}{c}71 \\
\text { (Japan) } \\
54 \\
\text { (US/Korea) }\end{array}$ & $\begin{array}{c}12 \\
\text { (Japan) } \\
11 \\
\text { (US/Korea) }\end{array}$ & $\begin{array}{c}26 \\
\text { (Japan) } \\
23 \\
\text { (US/Korea) }\end{array}$ \\
\hline GOG254 [25] & Recurrent & 35 & Sunitinib $50 \mathrm{mg} /$ day & 6.7 & 2.7 & 12.8 \\
\hline NRG-GY001 [26] & Recurrent & 13 & Cabozantinib $60 \mathrm{mg} /$ day & 0 & 3.6 & 8.1 \\
\hline
\end{tabular}

Abbreviations: TC*, Paclitaxel $180 \mathrm{mg} / \mathrm{m}^{2}$, Carboplatin AUC6 on day1 every 3weeks; TC**, Paclitaxel $175 \mathrm{mg} / \mathrm{m}^{2}$, Carboplatin AUC6 on day1 every 3 weeks; CPT-P, Irinotecan $60 \mathrm{mg} / \mathrm{m}^{2}$ on days $1,8,15$, Cisplatin $60 \mathrm{mg} / \mathrm{m}^{2}$ on day1 every 4 weeks; ORR, Objective response rate; PFS, Progression-free survival; OS, Overall survival. ${ }^{* * *} p<0.005$.

Based on preliminary studies conducted in Japan, irinotecan is expected to be effective for clear cell carcinoma. In a preliminary study using $\gamma \mathrm{H} 2 \mathrm{AX}$ (a DNA damage marker), Takatori et al. reported that the combination of irinotecan and cisplatin may be effective while assuming that the S-phase arrest and cytotoxic effects of irinotecan are theoretically effective because of the low ratio of S-phase cells and the low growth rate in clear cells [27].

The JGOG3014 trial was a clinical study conducted by the Japanese Gynecologic Oncology Group (JGOG). Targeting patients with ovarian clear cell carcinoma at stages Ic to IV who received initial chemotherapy, this phase II randomized trial compared TC therapy (paclitaxel $180 \mathrm{mg} / \mathrm{m}^{2}+$ carboplatin at area under the curve [AUC] 6 on day 1) and irinotecan + cisplatin (CPT-P) therapy (irinotecan $60 \mathrm{mg} / \mathrm{m}^{2}$ on days 1,8 , and $15+$ cisplatin $60 \mathrm{mg} / \mathrm{m}^{2}$ on day 1). CPT-11 is an anticancer drug developed in Japan with the mechanism of action of topoisomerase I inhibition. On the other hand, cisplatin is generally believed to exert its anticancer effects by interacting with DNA, inducing programmed cell death $[28,29]$. 
Progression-free survival (PFS) was slightly better with CPT-P therapy, but the difference was not significant. However, the subset analysis showed that the outcomes of CPT-P therapy were better than those of TC therapy in patients with residual tumors less than $2 \mathrm{~cm}$ in diameter. This trial also demonstrated the safety of CPT-P therapy, providing the basis for the phase III trial described below [22].

The JGOG3017 trial was a phase III randomized controlled trial for ovarian clear cell carcinomas. Targeting patients at stages I to IV who received postoperative chemotherapy, this trial compared standard TC and CPT-P therapies. In TC therapy, paclitaxel at a dose of $175 \mathrm{mg} / \mathrm{m}^{2}$ and carboplatin at AUC 6 were administered on day 1 and repeated every 3 weeks. In the CPT-P therapy, irinotecan (CPT-11) at a dose of $60 \mathrm{mg} / \mathrm{m}^{2}$ was administered on days 1,8 , and 15 and cisplatin at a dose of $60 \mathrm{mg} / \mathrm{m}^{2}$ was administered on day 1 and repeated every 4 weeks. Both therapies were administered for 6 cycles. In this trial, which enrolled 667 patients, the 2-year disease-free survival rates were $77.6 \%$ and $73.0 \%$ for TC and CPT-P therapies, respectively (hazard ratio $[\mathrm{HR}]=1.17$ ), and the 2 -year survival rates were $87.4 \%$ and $85.5 \%(\mathrm{HR}=1.13)$, respectively. The superiority of CPT-P therapy over TC therapy has not yet been demonstrated [23]. Based on these results, CPT-P therapy is currently used as an alternative to TC therapy in Japan.

The GOG268 trial was a phase II clinical trial in patients with ovarian clear cell carcinoma at stage III/IV who received TC and consolidation therapies combined with temsirolimus. Temsirolimus is a molecularly targeted drug that inhibits cell cycle progression and angiogenesis by blocking mTOR activity [30]. In TC therapy, 1 cycle lasting 3 weeks consisted of the administration of $175 \mathrm{mg} / \mathrm{m}^{2}$ paclitaxel and carboplatin at AUC 6 on day 1 in combination with temsirolimus administered at a dose of $25 \mathrm{mg} /$ body on days 1 and 8 . Six cycles were performed. Subsequently, consolidation therapy was administered from cycles 7 to 17. During each 3-week cycle of consolidation therapy, temsirolimus was administered at a dose of $25 \mathrm{mg} /$ body on days 1, 8, and 15. This trial enrolled 90 patients, including a total of 45 from the United States and South Korea and 45 from Japan. Exacerbation was detected in $22 \%$ of the patients during TC + temsirolimus therapy; 17 cycles of chemotherapy were completed by $28 \%$ of the patients. Among the patients with measurable lesions, complete and partial responses were, respectively, observed in $31 \%(n=4)$ and $23 \%(n=3)$ of the patients from the United States and South Korea and $6 \%(n=1)$ and $65 \%(n=11)$ of the patients from Japan. The median PFS and overall survival (OS) were, respectively, 11 and 23 months for the patients from the United States and South Korea and 12 and 26 months for the patients from Japan. In $54 \%$ of the patients who underwent optimal surgery, the PFS exceeded 12 months. However, comparison of PFS in the historical control group showed no significant difference [24].

The GOG254 trial examined the effectiveness of sunitinib in 35 patients with recurrence. Sunitinib is a highly potent, selective inhibitor of protein tyrosine kinases, including vascular endothelial growth factor receptor (VEGFR) and platelet derived growth factor receptor (PDGF). In the trial, 1 cycle of sunitinib therapy was set to last 6 weeks -4 weeks of administration at a dose of $50 \mathrm{mg}$ daily, followed by 2 weeks of a resting period. The therapy was administered until disease progression or intolerable toxicity was observed. Although the response rate was $6.7 \%, 16.7 \%$ of patients achieved a PFS of 6 months or longer. The median PFS and OS were 2.7 and 12.8 months, respectively. However, there were patients who developed grade 4 or 5 thrombocytopenia, anemia, acute renal failure, stroke, or allergic reactions [25].

Cabozantinib is an orally bioavailable multitargeted tyrosine kinase inhibitor whose primary targets are MET $($ IC50 $=1.8 \mathrm{nM})$, VEGFR2/KDR $($ IC50 $=0.035 \mathrm{nM})$ and RET $(\mathrm{IC} 50=3.8 \mathrm{nM})$. The NRG-GY001 trial evaluated the effectiveness of cabozantinib in 13 patients with recurrence. In the trial, 1 cycle of cabozantinib therapy consisted of oral administration of $60 \mathrm{mg}$ once daily for 4 weeks. The therapy was administered until disease progression or intolerable toxicity was observed. A PFS of 6 months or longer was achieved in $23 \%$ of the patients, 1 of whom received 23 cycles. The median PFS 
and OS were 3.6 and 8.1 months, respectively. However, 1 patient developed grade 5 thromboembolism [26].

The results of these trials did not change the standard primary or recurrent treatments for ovarian clear cell carcinoma.

\subsection{Ongoing or Planned Clinical Studies for Clear Cell Carcinoma}

Table 3 summarizes the clinical studies that have completed patient registration and are currently in the analysis stage and those that have been planned to be conducted in the future.

Table 3. Ongoing or planned clinical studies for ovarian clear cell carcinoma.

\begin{tabular}{ccccc}
\hline Table. & Patients & Phase & N & Arms/Treatments \\
\hline GOG283 [31] & Recurrent & II & 35 & Dasatinib 140 mg/day \\
NiCCC & Recurrent & II (Randomized) & 120 & SoC \\
(ENGOT-GYN1) [32] & Recurrent & II (basket) & 86 & Tazemetostat \\
NRG-GY-014 [33] & Recurrent & II & 14 & Pembrolizumab + Epacadostat \\
NRG-GY-016 [34] & Ceralasertib 160 mg \\
ATARI [35] & Recurrent & II & $40<,<116$ & + / - Olaparib 600mg $/$ day * \\
\hline
\end{tabular}

Abbreviations: SoC, Standerd of care[ Ovarian Cancer Patients: Paclitaxel $\left(80 \mathrm{mg} / \mathrm{m}^{2}\right)$ IV Day 1, 8, 15 every 28 days Pegylated Liposomal Doxorubicin (PLD) $\left(40 \mathrm{mg} / \mathrm{m}^{2}\right)$ IV every 28 days Topotecan $\left(4 \mathrm{mg} / \mathrm{m}^{2}\right)$ IV Day 1, 8, 15 every 28 days,Endometrial Cancer Patients: Carboplatin (AUC 5) and Paclitaxel $\left(175 \mathrm{mg} / \mathrm{m}^{2}\right.$ ) IV every 21 days Doxorubicin IV $\left(60 \mathrm{mg} / \mathrm{m}^{2}\right)$ every 21 days]; * Cohort 1A patients receive ceralasertib monotherapy $(160 \mathrm{mg}$ tablets twice daily on days 1-14 in a 28 day cycle). If no activity is observed in this cohort, cohort 1B will open, with the same patient population receiving ceralasertib plus olaparib in combination ( $160 \mathrm{mg}$ ceralasertib tablets once daily on days 1-7 and $300 \mathrm{mg}$ olaparib tablets twice daily continuously in a 28 day cycle). Patients with clear cell carcinomas (ovarian, endometrial, or endometriosis related) with no ARID1A loss enter cohort 2 and patients with other relapsed gynecological subtypes enter cohort 3, irrespective of ARID1A status. Both cohort 2 and cohort 3 patients receive combination therapy $(160 \mathrm{mg}$ ceralasertib tablets once daily on days $1-7$ and $300 \mathrm{mg}$ olaparib tablets twice daily continuously in a 28 day cycle).

Dasatinib is an oral available short-acting inhibitor of multiple tyrosine kinases. In the GOG283 trial, dasatinib at a dose of $140 \mathrm{mg} /$ body was administered to 35 patients with recurrent clear cell carcinoma of the ovary or endometrium with or without the confirmed expression of BRG-associated factor 250a. One cycle was set to last twenty-eight days, and the drug was administered until disease progression or intolerable toxicity was observed. Case accumulation has been completed, and analyses are currently in progress [31].

Nintedanib is a potent, orally available triple angiokinase inhibitor that targets VEGF, PDGF, and fibroblast growth factor (FGF) receptor signaling pathways [36]. The NiCCC (ENGOT-GYN1) trial is a phase II randomized trial that compares nintedanib with chemotherapy selected by physicians of patients with recurrent clear cell carcinoma of the ovary or endometrium. In the experimental arm, nintedanib at a dose of $200 \mathrm{mg} /$ day will be continuously administered until exacerbation, and the PFS will be compared to that of chemotherapy [32].

Tazemetostat is a first-in-class, selective, oral, mutant and wild-type enhancer of zeste homolog 2 (EZH2) inhibitor [37]. In the NRG-GY-014 trial, a 28-day cycle of tazemetostat therapy will be repeated for recurrent clear cell carcinomas of the ovary and endometrium, unless disease progression or intolerable toxicity is observed. The primary endpoint is the response rate, and this trial is planned to include 86 patients [33].

Epacadostat decreases tryptophan metabolism by inhibiting IDO1, which results in the enhanced proliferation of effector T cells and natural killer cells, the decreased apoptosis and increased activation of CD86 ${ }^{\text {high }}$ dendritic cells, and the reduced expansion of regulatory T cells [38]. The anti-PD-1 antibody pembrolizumab was tested in clinical trials as maintenance therapy for ovarian cancer [39]. In preclinical models, epacadostat plus an ICI suppressed tumor growth more effectively than single-agent treatment, primarily through reactivation of antitumor immunity [40]. In the NRG-GY-016 trial, which targets patients with recurrent clear cell carcinoma, epacadostat is orally administered on consecutive days and pembrolizumab was administered every 21 days. One cycle is set to last twenty-one 
days and repeated until disease progression or intolerable toxicity is observed. The primary endpoint is the response rate, and the secondary endpoints are safety, PFS, and OS. This trial enrolled 14 patients, and the enrollment was closed in February 2021 [34].

Ceralasertib (AZD6738), a potent, selective ataxia telangiectasia and Rad3-related kinase inhibitors, is under evaluation as monotherapy and in combination with chemotherapy, ionizing radiation, immunotherapy, and other anti-cancer drugs, including PARP inhibitors in a variety of genetic contexts [41]. The ATARI trial (ENGOT/GYN1/NCRI) is a phase II randomized trial comparing response rates between ceralasertib alone and in combination with olaparib in patients with gynecologic cancers, including recurrent clear cell carcinoma, with or without a confirmed ARID1A deficiency. This trial is planned to include at least 40 patients [35].

\subsection{New Pharmacotherapy for Clear Cell Carcinoma}

Immune checkpoint inhibitors are promising drugs. In a phase II clinical study of nivolumab (an anti-programmed cell death 1 antibody) involving patients with platinumresistant recurrent ovarian cancer, Hamanishi et al. reported that 2 of 20 patients achieved complete response. Clear cell carcinoma was diagnosed in one of the two patients, and serous carcinoma was diagnosed in the other. Notably, the latter had tumors with a gene expression profile similar to that of clear cell carcinoma [42]. Since this clinical study included only two patients with clear cell carcinoma, this histological type may be more sensitive to immune checkpoint inhibitors than other types.

Some PI3K pathway inhibitors using PIK3CA mutations as a target may be identified as effective drugs. TAS-117, an AKT inhibitor, is currently being investigated in a phase I clinical study on patients with clear cell carcinoma, including those positive for PIK3CA mutations [43].

Although the rate of TP53 mutation is low in clear cell carcinomas, the murine double minute 2 (MDM2) gene, which is involved in TP53 degradation, is more frequently expressed in this histological type than in other types. In clear cell carcinoma lines without TP53 mutations, MDM2 inhibitors have exhibited antitumor effects both in vitro and in vivo [44]. Consequently, MDM2 inhibitors are currently being investigated in clinical studies.

ARID1A deficiency is observed in gynecological cancers such as ovarian cancer. ARID1A gene mutations can also be identified by gene panel testing. Metabolome-targeted anticancer drugs are still unexplored, but they are promising and new drug discovery, and personalized treatment is expected [18].

\section{Mucinous Carcinoma}

\subsection{Biological Characteristics}

Many cases of ovarian mucinous carcinoma have been reported to metastasize from gastrointestinal carcinomas [45]. In Japan, primary ovarian mucinous carcinoma accounts for $11 \%$ of epithelial ovarian cancer cases [46]. In a clinical study conducted in patients with epithelial ovarian cancer at the International Federation of Gynecology and Obstetrics (FIGO) stages III to IV by the Gynecologic Oncology Group (GOG), 54 patients (1.5\%) had mucinous carcinoma. Of the 44 patients who underwent central pathological review, approximately $60 \%$ had metastatic ovarian cancer [47]. In a multicenter clinical study conducted in Japan, 87 of 151 patients (57.6\%) with ovarian mucinous carcinoma had metastatic ovarian cancer [48]. Thus, for the diagnosis of primary ovarian mucinous carcinoma, it is important to exclude metastatic variants and to check the presence or absence of interstitial infiltrate while monitoring the tumor diameter and the characteristics of individual lesions [49].

In ovarian mucinous carcinoma, abnormalities in the tumor protein p53 (TP53) gene, which are frequently observed in serous carcinoma, are relatively uncommon [34]. Abnormalities in the KRAS gene, which are common in gastrointestinal carcinoma, were observed in $32-56 \%$ of patients [50-53], and the human epithelial growth factor receptor 
2 (HER2) gene was amplified in 18\% [54]. However, no abnormalities were observed in the V-raf murine sarcoma viral oncogene homolog B1 (BRAF) gene [53]. Table 4 summarizes the frequencies of genetic abnormalities in mucinous ovarian and colorectal carcinomas [50-60]. Since ovarian mucinous carcinomas frequently express proteins such as cytokeratin (CK) 7, CK 20, caudal-related homeobox transcription factor (CDX) 2, mucin (MUC) 2, and MUC5AC, they are suggested to have biological characteristics similar to those of gastrointestinal carcinomas $[61,62]$. Table 5 summarizes the frequencies of protein expression in mucinous ovarian and colorectal carcinomas [63-73].

Table 4. Frequency of molecular alterations in ovarian and colorectal mucinous carcinomas .

\begin{tabular}{ccc}
\hline & $\begin{array}{c}\text { Primary Ovarian } \\
\text { Mucinous Carcinomas }\end{array}$ & $\begin{array}{c}\text { Primary Colorectal } \\
\text { Mucinous Carcinomas }\end{array}$ \\
\hline KRAS mutations & $32-56 \%[50-53]$ & $23-38 \%[55-57]$ \\
HER2 amplification & $18 \%[54]$ & $<1 \%[58]$ \\
BRAF mutations & $0 \%[53]$ & $14-28 \%[56,57,59]$ \\
TP53 mutation & $26 \%[50]$ & $20-48 \%[59,60]$ \\
\hline
\end{tabular}

Abbreviations: KRAS, V-Ki-ras2 Kirsten rat sarcoma viral oncogene homolog; HER2, human epithelial growth factor receptor 2; BRAF, V-raf murine sarcoma viral oncogene homolog B1; TP53, Tumor protein p53.

Table 5. Frequency of expression of selected markers used for differential diagnosis of ovarian and colorectal mucinous carcinomas.

\begin{tabular}{ccc}
\hline$\cdot$ & $\begin{array}{c}\text { Primary Ovarian } \\
\text { Mucinous Carcinomas }\end{array}$ & $\begin{array}{c}\text { Primary Colorectal } \\
\text { Mucinous Carcinomas }\end{array}$ \\
\hline CK7 & $79-100 \%[63-65]$ & $10 \%[69]$ \\
CK20 & $56-98 \%[64.65]$ & $100 \%[64]$ \\
CDX2 & $18-42 \%[63,66]$ & $59 \%[70]$ \\
MUC2 & $100 \%[67]$ & $86-96 \%[67,71-73]$ \\
MUC5AC & $50-100 \%[64,68]$ & $2-33 \%[70,73]$ \\
\hline
\end{tabular}

Abbreviations: CK7, Cytokeratin 7; CK20, Cytokeratin 20; CDX2, Caudal-related homeobox transcription factor 2; MUC2, Mucin 2; MUC5AC, Mucin 5AC.

\subsection{Chemotherapy for Mucinous Carcinoma}

Table 6 shows the previously reported outcomes of chemotherapy [48,74-77]. In a study involving 27 patients with mucinous carcinoma and 54 patients with serous carcinoma, the response rates to chemotherapy, disease-free survival, and OS were all worse in the latter [74]. In a retrospective study comprising 420 patients with epithelial ovarian cancer at FIGO stages III to IV, who received combination chemotherapy with paclitaxel and platinum-containing drugs, 24 patients with mucinous carcinoma exhibited a significantly lower response rate to chemotherapy ( $45 \%$ vs. $87 \%$ ) and shorter median survival (15.4 months vs. 47.7 months) than 367 patients with serous carcinoma [75]. In a Japanese study conducted by Shimada et al., the response rate to chemotherapy in patients with mucinous carcinoma was $12.5 \%$, which was significantly lower than the $68.4 \%$ in patients with serous carcinoma [48]. Thus, TC therapy, which is the standard chemotherapy for epithelial ovarian cancer, cannot be considered an effective treatment option for mucinous carcinoma, thereby necessitating the urgent development of new therapies.

Since mucinous ovarian and gastrointestinal carcinomas have similar biological characteristics, the regimens used for the latter have been attracting attention. Oxaliplatin (L-OHP) is a platinum-based anti-cancer drug and we have reported its efficacy for adenocarcinoma of the uterine cervix. L-OHP binds to the DNA of cancer cells and induces DNA replication and apoptosis of cancer cells, resulting in an anti-tumor effect [78]. 5-Fluorouracil (5-FU) is a fluoropyrimidine antimetabolism agent that exhibits antitumor effects by inhibiting DNA synthesis [79]. Using cell lines derived from ovarian mucinous carcinoma, Sato et al. demonstrated that a combination of L-OHP and 5-FU inhibited cell proliferation by $50 \%$ or more in four of five cell lines. They also reported that the combi- 
nation therapy significantly increased the survival of nude mouse models of cancerous peritonitis, compared with L-OHP or 5-FU monotherapy [80]. Thus, combining L-OHP and 5-FU is a promising strategy for the treatment of ovarian mucinous carcinoma.

Table 6. Previous reports of chemotherapy for mucinous carcinoma.

\begin{tabular}{ccccccc}
\hline Author & Patients & N & Regimen & OOR (\%) & Median PFS & Median OS \\
\hline Shimada M [48] & Stage I-IV & 24 & Platinum based regimen & 12.5 & NA & NA \\
Hess V [74] & Stage III/IV & 19 & Platinum based regimen & 26.3 & 5.7 & 12.0 \\
Bamias A [75] & Stage III/IV & 24 & Paclitaxel/platinum & 45.0 & NA & 15.4 \\
Pectasides D [76] & Stage III/IV & 47 & Platinum based regimen & 38.5 & 11.8 (TTP) & 33.2 \\
Pisano C [77] & Stage I-IV & 19 & Platinum based regimen & 42.1 & NA & NA \\
\hline
\end{tabular}

Abbreviations: ORR, Objective response rate; PFS, Progression-free survival; OS, Overall survival; NA, not available; TTP, Time to progression.

\subsection{Clinical Studies Using L-OHP and 5-FU for Mucinous Carcinoma}

Kurnit et al. reported a retrospective cohort study of 52 patients with ovarian mucinous carcinoma that compared 5-FU, capecitabine, and L-OHP in 26 patients treated with the regimens for gastrointestinal carcinoma and 26 patients treated with the regimens for ovarian cancer. In this study, the gastrointestinal carcinoma regimens improved OS in patients with ovarian mucinous carcinoma requiring postoperative chemotherapy (HR: 0.2, 95\% confidence interval: $0.1-0.8, p=0.01$ ) [81].

The mEOC/GOG241 trial was a phase III randomized control trial that targeted patients with ovarian mucinous carcinoma at stages II to IV undergoing initial treatment and those with recurrent ovarian mucinous carcinoma at stage I who had no history of chemotherapy. This trial compared TC therapy with L-OHP + capecitabine combination therapy (XELOX therapy). Capecitabine is a prodrug of 5-FU. These therapies were then compared after the addition of the angiogenesis inhibitor bevacizumab. This trial compared and analyzed only 50 patients because of the delayed accumulation of cases. Compared with TC therapy, XELOX therapy did not improve survival $(\mathrm{HR}=0.78)$, even after the addition of bevacizumab $(\mathrm{HR}=1.04)$ [82].

In Japan, a phase II clinical study was conducted on S-1 + L-OHP therapy for advanced and recurrent ovarian mucinous carcinoma. S-1 is also a prodrug of 5-FU. The primary endpoint was the response rate, and the secondary endpoints were the incidence of adverse events, PFS, and OS. The response and disease control (which included stable disease) rates were $12 \%$ and $70 \%$, respectively. These results demonstrated the importance of salvage chemotherapy for advanced and recurrent cancers, which are considered to have poor prognoses. However, based on the central pathological review, metastatic cancer was diagnosed in 19 of the 33 patients. This reaffirmed the low rate of accurate diagnosis of primary mucinous carcinoma [83].

However, these anticancer drugs did not change the standard primary or recurrent treatments for ovarian mucinous carcinoma.

\subsection{New Pharmacotherapy for Mucinous Carcinoma}

Molecular target drugs have been attracting attention as new therapies for mucinous carcinomas, which are resistant to platinum-based chemotherapy [49]. Compared to colorectal cancer, HER2-neu gene amplification is relatively more common in ovarian mucinous carcinoma, it responds to trastuzumab, a humanized monoclonal antibody targeting HER2 either alone or in combination with oral lapatinib, a tyrosine kinase inhibitor [54,84]. Furthermore, an in vivo study showed that cetuximab, an epithelial growth factor receptor inhibitor, is effective for the treatment of mucinous carcinomas without KRAS mutations [85]. Another study demonstrated that this inhibitor exerts a synergistic effect by inhibiting mitogen-activated protein kinase (MEK) and PI3K in ovarian mucinous carcinoma cell lines with KRAS mutations [86]. In a phase I clinical study of a rare ovarian cancer subtype, Spreafico reported that favorable objective responses were obtained by simultaneous inhibition of MEK and PI3K in patients with KRAS mutation-associated ovarian 
cancer [87]. The use of such molecular target drugs is expected to facilitate the development of new therapeutic strategies for advanced and recurrent ovarian mucinous carcinomas.

\section{Conclusions}

Ovarian cancer is diverse at the molecular level, and clear cell and mucinous carcinomas exhibit low sensitivity to chemotherapy. Although chemotherapy regimens for ovarian clear cell and mucinous carcinomas have been evaluated by numerous clinical studies, they have failed to exhibit treatment outcomes superior to those of TC therapy. The identification of biomarkers and development of therapeutic drugs specific to each type of ovarian cancer are anticipated. For ovarian clear cell carcinoma, in which the $\mathrm{PI} 3 \mathrm{~K} / \mathrm{AKT} / \mathrm{mTOR}$ pathway and the MDM2 gene are prognostic factors, AKT and MDM2 inhibitors may prove to be promising therapeutic drugs in the future. The biomakers for ovarian mucinous carcinoma, including the KRAS and HER2-neu genes, MEK, and $P I 3 K$, and molecular target drugs such as trastuzumab, lapatinib, and cetuximab have been gaining attention. We hope that molecular target drugs and immune checkpoint inhibitors targeting these genomic alterations will be developed and clinically applied in the future.

Author Contributions: Conceptualization, T.S.; Literature Search, S.T., M.A., H.T., E.T., Y.K., T.N. and M.K.; Writing-Original Draft Preparation, T.S.; Writing-Review and Editing, T.S., H.T., E.T., Y.K., T.N., M.K., T.B. and H.I. All authors have read and agreed to the published version of the manuscript.

Funding: This research received no external funding.

Conflicts of Interest: The authors declare no conflict of interest.

\section{References}

1. Siegel, R.L.; Miller, K.D.; Jemal, A. Cancer statistics, 2017. CA Cancer J. Clin. 2017, 67, 7-30. [CrossRef]

2. Banerjee, S.; Moore, K.N.; Colombo, N.; Scambia, G.; Kim, B.G.; Oaknin, A.; Friedlander, M.; Lisyanskaya, A.; Floquet, A.; Leary, A.; et al. Maintenance olaparib for patients with newly diagnosed advanced ovarian cancer and a BRCA mutation (SOLO1/GOG 3004): 5-year follow-up of a randomised, double-blind, placebo-controlled, phase 3 trial. Lancet Oncol. 2021, 22, 1721-1731. [CrossRef]

3. Ray-Coquard, I.; Pautier, P.; Pignata, S.; Pérol, D.; González-Martín, A.; Berger, R.; Fujiwara, K.; Vergote, I.; Colombo, N.; Mäenpää, J.; et al. Olaparib plus bevacizumab as first-line maintenance in ovarian cancer. N. Engl. J. Med. 2019, 381, $2416-2428$. [CrossRef] [PubMed]

4. González-Martín, A.; Pothuri, B.; Vergote, I.; DePont Christensen, R.; Graybill, W.; Mirza, M.R.; McCormick, C.; Lorusso, D.; Hoskins, P.; Freyer, G.; et al. Niraparib in Patients with Newly Diagnosed Advanced Ovarian Cancer. N. Engl. J. Med. 2019, 381, 2391-2402. [CrossRef] [PubMed]

5. Winter, W.E., 3rd; Maxwell, G.L.; Tian, C.; Carlson, J.W.; Ozols, R.F.; Rose, P.G.; Markman, M.; Armstrong, D.K.; Muggia, F.; McGuire, W.P. Gynecologic Oncology Group Study. Prognostic factors for stage III epithelial ovarian cancer: A Gynecologic Oncology Group Study. J. Clin. Oncol. 2007, 25, 3621-3627. [CrossRef] [PubMed]

6. Horiuchi, A.; Itoh, K.; Shimizu, M.; Nakai, I.; Yamazaki, T.; Kimura, K.; Suzuki, A.; Shiozawa, I.; Ueda, N.; Konishi, I. Toward understanding the natural history of ovarian carcinoma development: A clinicopathological approach. Gynecol. Oncol. 2003, 88, 309-317. [CrossRef]

7. Sáinz de la Cuesta, R.; Izquierdo, M.; Cañamero, M.; Granizo, J.J.; Manzarbeitia, F. Icreased prevalence of p53 overexpresion form typical endometriosis to atypical endometriosis and ovarian associated with endometriosis. Eur. J. Obstet. Gynecol. Report Biol. 2004, 113, 87-93. [CrossRef]

8. Obata, K.; Hoshiai, H. Common genetic changes between endometriosis and ovarian cancer. Gynecol. Obstet. Invest. 2000, 50, 39-43. [CrossRef] [PubMed]

9. Itamochi, H.; Kigawa, J.; Akeshima, R.; Sato, S.; Kamazawa, S.; Takahashi, M.; Kanamori, Y.; Suzuki, M.; Ohwada, M.; Terakawa, N. Mechanisms of cisplatin resistance in clear cell carcinoma of the ovary. Oncology 2002, 62, 349-353. [CrossRef] [PubMed]

10. Yamagami, W.; Nagase, S.; Takahashi, F.; Ino, K.; Hachisuga, T.; Aoki, D.; Katabuchi, H. Clinical statistics of gynecologic cancers in Japan. J. Gynecol. Oncol. 2017, 28, e32. [CrossRef] [PubMed]

11. McGuire, W.P.; Hoskins, W.J.; Brady, M.F.; Kucera, P.R.; Partridge, E.E.; Look, K.Y.; Clarke-Pearson, D.L.; Davidson, M. Cyclophosphamide and cisplatin compared with paclitaxel and cisplatin in patients with stage III and stage IV ovarian cancer. N. Engl. J. Med. 1996, 334, 1-6. [CrossRef]

12. Piccart, M.J.; Bertelsen, K.; James, K.; Cassidy, J.; Mangioni, C.; Simonsen, E.; Stuart, G.; Kaye, S.; Vergote, I.; Blom, R.; et al. Randomized intergroup trial of cisplatin-paclitaxel versus cisplatin-cyclophosphamide in women with advanced epithelial ovarian cancer: Three-year results. J. Natl. Cancer Inst. 2000, 92, 699-708. [CrossRef] [PubMed] 
13. Ozols, R.F.; Bundy, B.N.; Greer, B.E.; Fowler, J.M.; Clarke-Pearson, D.; Burger, R.A.; Mannel, R.S.; DeGeest, K.; Hartenbach, E.M.; Baergen, R. Phase III trial of carboplatin and paclitaxel compared with cisplatin and paclitaxel in patients with optimally resected stage III ovarian cancer: A Gynecologic Oncology Group Study. J. Clin. Oncol. 2003, 21, 3194-3200. [CrossRef] [PubMed]

14. Du Bois, A.; Luck, H.J.; Meier, W.; Adams, H.P.; Möbus, V.; Costa, S.; Bauknecht, T.; Richter, B.; Warm, M.; Schröder, W.; et al. A randomized clinical trial of cisplatin/paclitaxel versus carboplatin/paclitaxel as first-line treatment of ovarian cancer. J. Natl. Cancer Inst. 2003, 95, 1320-1329. [CrossRef] [PubMed]

15. McGuire, W.P.; Rowinsky, E.K.; Rosenshein, N.B.; Grumbine, F.C.; Ettinger, D.S.; Armstrong, D.K.; Donehower, R.C. Taxol: A unique antineoplastic agent with significant activity in advanced ovarian epithelial neoplasms. Ann. Intern. Med. 1989, 111, 273-279. [CrossRef] [PubMed]

16. Sugiyama, T.; Kamura, T.; Kigawa, J.; Terakawa, N.; Kikuchi, Y.; Kita, T.; Suzuki, M.; Sato, I.; Taguchi, K. Clinical characteristics of clear cell carcinoma of the ovary: A distinct histologic type with poor prognosis and resistance to platinum-based chemotherapy. Cancer 2000, 88, 2584-2589. [CrossRef]

17. Sugiyama, T.; Fujiwara, K. Clear Cell Carcinoma of the Ovary; ASCO Educational Book: Alexandria, VA, USA, $2007 ;$ pp. $313-326$.

18. Murakami, R.; Matsumura, N.; Brown, J.B.; Higasa, K.; Tsutsumi, T.; Kamada, M.; Abou-Taleb, H.; Hosoe, Y.; Kitamura, S.; Yamaguchi, K.; et al. Exome Sequencing Landscape Analysis in Ovarian Clear Cell Carcinoma Shed Light on Key Chromosomal Regions and Mutation Gene Networks. Am. J. Pathol. 2017, 187, 2246-2258. [CrossRef]

19. Itamochi, H.; Oishi, T.; Oumi, N.; Takeuchi, S.; Yoshihara, K.; Mikami, M.; Yaegashi, N.; Terao, Y.; Takehara, K.; Ushijima, K.; et al. Whole-genome sequencing revealed novel prognostic biomarkers and promising targets for therapy of ovarian clear cell carcinoma. Br. J. Cancer 2017, 117, 717-724. [CrossRef]

20. Amano, Y.; Mandai, M.; Yamaguchi, K.; Matsumura, N.; Kharma, B.; Baba, T.; Abiko, K.; Hamanishi, J.; Yoshioka, Y.; Konishi, I. Metabolic alterations caused by HNF1 $\beta$ expression in ovarian clear cell carcinoma contribute to cell survival. Oncotarget 2015, 6, 26002-26017. [CrossRef]

21. Takahashi, K.; Takenaka, M.; Okamoto, A.; Bowtell, D.D.L.; Kohno, T. Treatment Strategies for ARID1A-Deficient Ovarian Clear Cell Carcinoma. Cancers 2021, 13, 1769. [CrossRef]

22. Takakura, S.; Takano, M.; Takahashi, F.; Saito, T.; Aoki, D.; Inaba, N.; Sugiyama, T.; Ochiai, K.; Japanese Gynecologic Oncology Group. Japanese Gynecologic Oncology Group. Randomized Phase II trail of paclitaxel plus carboplatin therapy versus irinotecan plus cisplatin therapy as first-line chemotherapy for clear cell adenocarcinoma of the ovary: A JGOG study. Int. J. Gynecol. Cancer 2010, 20, 240-247. [CrossRef]

23. Sugiyama, T.; Okamoto, A.; Enomoto, T.; Hamano, T.; Aotani, E.; Terao, Y.; Suzuki, N.; Mikami, M.; Yaegashi, N.; Kato, K.; et al. Randomized Phase III Trial of Irinotecan Plus Cisplatin Compared With Paclitaxel Plus Carboplatin As First-Line Chemotherapy for Ovarian Clear Cell Carcinoma: JGOG3017/GCIG Trial. J. Clin. Oncol. 2016, 34, 2881-2887. [CrossRef] [PubMed]

24. A Phase II Evaluation of Temsirolimus in Combination with Carboplatin and Paclitaxel Followed by Temsirolimus Consolidation as First-Line Therapy in the Treatment of Stage III-IV Clear Cell Carcinoma of the Ovary. Available online: https://ascopubs.org/ doi/abs/10.1200/JCO.2016.34.15_suppl.5531 (accessed on 19 October 2021).

25. Chan, J.K.; Brady, W.; Monk, B.J.; Brown, J.; Shahin, M.S.; Rose, P.G.; Kim, J.H.; Secord, A.A.; Walker, J.L.; Gershenson, D.M. A phase II evaluation of sunitinib in the treatment of persistent or recurrent clear cell ovarian carcinoma: An NRG Oncology/Gynecologic Oncology Group Study (GOG-254). Gynecol. Oncol. 2018, 150, 247-252. [CrossRef] [PubMed]

26. Konstantinopoulos, P.A.; Brady, W.E.; Farley, J.; Armstrong, A.; Uyar, D.S.; Gershenson, D.M. Phase II Study of Single-Agent Cabozantinib in Patients with Recurrent Clear Cell Ovarian, Primary Peritoneal or Fallopian Tube Cancer (NRG-GY001). Gynecol. Oncol. 2018, 150, 9-13. [CrossRef]

27. Takatori, E.; Shoji, T.; Kumagai, S.; Sawai, T.; Kurose, A.; Sugiyama, T. Are platinum agents, paclitaxel and irinotecan effective for clear cell carcinoma of the ovary? DNA damage detected with gammaH2AX induced by anticancer agents. J. Ovarian Res. 2012, 5, 16. [CrossRef] [PubMed]

28. Shoji, T.; Takatori, E.; Omi, H.; Kagabu, M.; Honda, T.; Futagami, M.; Yokoyama, Y.; Kaiho, M.; Tokunaga, H.; Otsuki, T.; et al. A phase II study of irinotecan and pegylated liposomal doxorubicin in platinum-resistant recurrent ovarian cancer (Tohoku Gynecologic Cancer Unit 104 study). Cancer Chemother. Pharmacol. 2017, 80, 355-361. [CrossRef]

29. Shoji, T.; Takeshita, R.; Saito, T.; Aida, T.; Sasou, S.; Baba, T. A case of primary ovarian signet-ring cell carcinoma treated with S-1/CDDP therapy. J. Ovarian Res. 2020, 13, 33. [CrossRef]

30. Takatori, E.; Shoji, T.; Miura, Y.; Takada, A.; Takeuchi, S.; Sugiyama, T. Effective use of everolimus as salvage chemotherapy for ovarian clear cell carcinoma: A case report. Onco. Targets Ther. 2014, 7, 165-169.

31. Dasatinib in Treating Patients with Recurrent or Persistent Ovarian, Fallopian Tube, Endometrial or Peritoneal Cancer. Available online: https: / / clinicaltrials.gov/ct2/show / NCT02059265\#armgroup (accessed on 19 October 2021).

32. Study Of Nintedanib Compared To Chemotherapy in Patients with Recurrent Clear Cell Carcinoma Of The Ovary Or Endometrium (NiCCC). Available online: https:/ / www.clinicaltrials.gov/ct2/show/NCT02866370 (accessed on 19 October 2021).

33. A Phase II Study of Tazemetostat for Recurrent or Persistent Endometrioid or Clear Cell Ovarian Cancer or Uterine Endometrioid Cancer. Available online: https://www.mskcc.org/cancer-care/clinical-trials/19-193 (accessed on 19 October 2021).

34. Testing Whether the Combination of Two Immunotherapy Drugs Have Activity in Recurrent or Persistent Clear Cell Ovarian Cancer. Available online: https:/ / clinicaltrials.gov/ct2/show / NCT03602586 (accessed on 19 October 2021). 
35. Banerjee, S.; Stewart, J.; Porta, N.; Toms, C.; Leary, A.; Lheureux, S.; Khalique, S.; Tai, J.; Attygalle, A.; Vroobel, K.; et al. ATARI trial: ATR inhibitor in combination with olaparib in gynecological cancers with ARID1A loss or no loss (ENGOT/GYN1/NCRI). Int. J. Gynecol. Cancer 2021, 31, 1471-1475. [CrossRef]

36. Barra, F.; Laganà, A.S.; Ghezzi, F.; Casarin, J.; Ferrero, S. Nintedanib for Advanced Epithelial Ovarian Cancer: A Change of Perspective? Summary of Evidence from a Systematic Review. Gynecol. Obstet. Investig. 2019, 84, 107-117. [CrossRef]

37. Morschhauser, F.; Tilly, H.; Chaidos, A.; McKay, P.; Phillips, T.; Assouline, S.; Batlevi, C.L.; Campbell, P.; Ribrag, V.; Damaj, G.L.; et al. Tazemetostat for patients with relapsed or refractory follicular lymphoma: An open-label, single-arm, multicentre, phase 2 trial. Lancet Oncol. 2020, 21, 1433-1442. [CrossRef]

38. Mitchell, T.C.; Hamid, O.; Smith, D.C.; Bauer, T.M.; Wasser, J.S.; Olszanski, A.J.; Luke, J.J.; Balmanoukian, A.S.; Schmidt, E.V.; Zhao, Y.; et al. Epacadostat Plus Pembrolizumab in Patients With Advanced Solid Tumors: Phase I Results From a Multicenter, Open-Label Phase I/II Trial (ECHO-202/KEYNOTE-037). J. Clin. Oncol. 2018, 36, 3223-3230. [CrossRef]

39. Shoji, T.; Sato, C.; Tomabechi, H.; Takatori, E.; Kaido, Y.; Nagasawa, T.; Kagabu, M.; Baba, T. Expectations and Challenges of First-Line Maintenance Therapy for Advanced Ovarian Cancer. Medicina 2021, 57, 501. [CrossRef] [PubMed]

40. Spranger, S.; Koblish, H.K.; Horton, B.; Scherle, P.A.; Newton, R.; Gajewski, T.F. Mechanism of tumor rejection with doublets of CTLA-4, PD-1/PD-L1, or IDO blockade involves restored IL-2 production and proliferation of CD8 $\left(^{+}\right) \mathrm{T}$ cells directly within the tumor microenvironment. J. Immunother. Cancer 2014, 2, 3. [CrossRef] [PubMed]

41. Shah, P.D.; Wethington, S.L.; Pagan, C.; Latif, N.; Tanyi, J.; Martin, L.P.; Morgan, M.; Burger, R.A.; Haggerty, A.; Zarrin, H.; et al. Combination ATR and PARP Inhibitor (CAPRI): A phase 2 study of ceralasertib plus olaparib in patients with recurrent, platinum-resistant epithelial ovarian cancer. Gynecol. Oncol. 2021, 163, 246-253. [CrossRef]

42. Hamanishi, J.; Mandai, M.; Ikeda, T.; Minami, M.; Kawaguchi, A.; Murayama, T.; Kanai, M.; Mori, Y.; Matsumoto, S.; Chikuma, S.; et al. Safety and Antitumor Activity of Anti-PD-1 Antibody, Nivolumab, in Patients With Platinum-Resistant Ovarian Cancer. J. Clin. Oncol. 2015, 33, 4015-4022. [CrossRef]

43. Yunokawa, M.; Takahashi, S.; Aoki, D.; Yonemori, K.; Hara, H.; Hasegawa, K.; Takehara, K.; Harano, K.; Nomura, H.; Noguchi, E.; et al. First-in-human phase I study of TAS-117, an allosteric AKT inhibitor, in patients with advanced solid tumours. Ann. Oncol. 2019, 30 (Suppl. S5), v169. [CrossRef]

44. Makii, C.; Oda, K.; Ikeda, Y.; Sone, K.; Hasegawa, K.; Uehara, Y.; Nishijima, A.; Asada, K.; Koso, T.; Fukuda, T.; et al. MDM2 is a potential therapeutic target and prognostic factor for ovarian clear cell carcinomas with wild type TP53. Oncotarget 2016, 15, 75328-75338. [CrossRef] [PubMed]

45. Seidman, J.D.; Kurman, R.J.; Ronnett, B.M. Primary and metastatic mucinous adenocarcinomas in the ovaries: Incidence in routine practice with a new approach to improve intraoperative diagnosis. Am. J. Surg. Pathol. 2003, 27, 985-993. [CrossRef]

46. Saito, T.; Takahashi, F.; Katabuchi, H. 2016 Committee on Gynecologic Oncology of the Japan Society of Obstetrics and Gynecology. Annual Report of the Committee on Gynecologic Oncology, Japan Society of Obstetrics and Gynecology: Patient Annual Report for 2014 and Treatment Annual Report for 2009. J. Obstet. Gynaecol. Res. 2017, 43, 1667-1677.

47. Zaino, R.J.; Brady, M.F.; Lele, S.M.; Michael, H.; Greer, B.; Bookman, M.A. Advanced stage mucinous adenocarcinoma of the ovary is both rare and highly lethal: A Gynecologic Oncology Group study. Cancer 2011, 117, 554-562. [CrossRef] [PubMed]

48. Shimada, M.; Kigawa, J.; Ohishi, Y.; Yasuda, M.; Suzuki, M.; Hiura, M.; Nishimura, R.; Tabata, T.; Sugiyama, T.; Kaku, T. Clinicopathological characteristics of mucinous adenocarcinoma of the ovary. Gynecol. Oncol. 2009, 113, 331-334. [CrossRef] [PubMed]

49. Morice, P.; Gouy, S.; Leary, A. Mucinous Ovarian Carcinoma. N. Engl. J. Med. 2019, 380, 1256-1266. [CrossRef]

50. Pieretti, M.; Hopenhayn-Rich, C.; Khattar, N.H.; Cao, Y.; Huang, B.; Tucker, T.C. Heterogeneity of ovarian cancer: Relationships among histological group, stage of disease, tumor markers, patient characteristics, and survival. Cancer Investig. 2002, 20, 11-23. [CrossRef] [PubMed]

51. Ichikawa, Y.; Nishida, M.; Suzuki, H.; Yoshida, S.; Tsunoda, H.; Kubo, T.; Uchida, K.; Miwa, M. Mutation of K-ras protooncogene is associated with histological subtypes in human mucinous ovarian tumors. Cancer Res. 1994, 54, 33-35. [PubMed]

52. Mandai, M.; Konishi, I.; Kuroda, H.; Komatsu, T.; Yamamoto, S.; Nanbu, K.; Matsushita, K.; Fukumoto, M.; Yamabe, H.; Mori, T. Heterogeneous distribution of K-ras-mutated epithelia in mucinous ovarian tumors with special reference to histopathology. Hum. Pathol. 1998, 29, 34-40. [CrossRef]

53. Gemignani, M.L.; Schlaerth, A.C.; Bogomolniy, F.; Barakat, R.R.; Lin, O.; Soslow, R.; Venkatraman, E.; Boyd, J. Role of KRAS and BRAF gene mutations in mucinous ovarian carcinoma. Gynecol. Oncol. 2003, 90, 378-381. [CrossRef]

54. McAlpine, J.N.; Wiegand, K.C.; Vang, R.; Ronnett, B.M.; Adamiak, A.; Köbel, M.; Kalloger, S.E.; Swenerton, K.D.; Huntsman, D.G.; Gilks, C.B.; et al. HER2 overexpression and amplification is present in a subset of ovarian mucinous carcinomas and can be targeted with trastuzumab therapy. BMC Cancer 2009, 9, 433. [CrossRef]

55. Ikeda, S.; Shimizu, Y.; Fujimori, M.; Ishizaki, Y.; Kurihara, T.; Ojima, Y.; Okajima, M.; Asahara, T. Immunohistochemical and mutational analyses of beta-catenin, Ki-ras, and p53 in two subtypes of colorectal mucinous carcinoma. Clin. Cancer Res. 2003, 9, 5660-5665.

56. Yoshitake, N.; Fujii, S.; Mukawa, K.; Tominaga, K.; Fukui, H.; Ichikawa, K.; Tomita, S.; Ono, Y.; Imai, Y.; Terano, A.; et al. Mutational analysis of the BRAF gene in colorectal mucinous carcinoma in association with histological configuration. Oncol. Rep. 2007, 17, 9-15. [CrossRef] [PubMed] 
57. Ogino, S.; Brahmandam, M.; Cantor, M.; Namgyal, C.; Kawasaki, T.; Kirkner, G.; Meyerhardt, J.A.; Loda, M.; Fuchs, C.S. Distinct molecular features of colorectal carcinoma with signet ring cell component and colorectal carcinoma with mucinous component. Mod. Pathol. 2006, 19, 59-68. [CrossRef]

58. Marx, A.H.; Burandt, E.C.; Choschzick, M.; Simon, R.; Yekebas, E.; Kaifi, J.T.; Mirlacher, M.; Atanackovic, D.; Bokemeyer, C.; Fiedler, W.; et al. Heterogenous high-level HER-2 amplification in a small subset of colorectal cancers. Hum. Pathol. 2010, 41, 1577-1585. [CrossRef] [PubMed]

59. Song, G.A.; Deng, G.; Bell, I.; Kakar, S.; Sleisenger, M.H.; Kim, Y.S. Mucinous carcinomas of the colorectum have distinct molecular genetic characteristics. Int. J. Oncol. 2005, 26, 745-750. [CrossRef] [PubMed]

60. Hanski, C.; Tiecke, F.; Hummel, M.; Hanski, M.L.; Ogorek, D.; Rolfs, A.; Schmitt-Gräff, A.; Stein, H.; Riecken, E.O. Low frequency of p53 gene mutation and protein expression in mucinous colorectal carcinomas. Cancer Lett. 1996, 103, 163-170. [CrossRef]

61. Harrison, M.L.; Jameson, C.; Gore, M.E. Mucinous ovarian cancer. Int. J. Gynecol. Cancer. 2008, 18, 209-214. [CrossRef] [PubMed]

62. Kelemen, L.E.; Köbel, M. Mucinous carcinomas of the ovary and colorectum: Different organ, same dilemma. Lancet Oncol. 2011, 12, 1071-1080. [CrossRef]

63. Tabrizi, A.D.; Kalloger, S.E.; Köbel, M.; Cipollone, J.; Roskelley, C.D.; Mehl, E.; Gilks, C.B. Primary ovarian mucinous carcinoma of intestinal type: Significance of pattern of invasion and immunohistochemical expression profile in a series of 31 cases. Int. J. Gynecol. Pathol. 2010, 29, 99-107. [CrossRef] [PubMed]

64. Ji, H.; Isacson, C.; Seidman, J.D.; Kurman, R.J.; Ronnett, B.M. Cytokeratins 7 and 20, Dpc4, and MUC5AC in the distinction of metastatic mucinous carcinomas in the ovary from primary ovarian mucinous tumors: Dpc4 assists in identifying metastatic pancreatic carcinomas. Int. J. Gynecol. Pathol. 2002, 2, 391-400. [CrossRef]

65. Vang, R.; Gown, A.M.; Barry, T.S.; Wheeler, D.T.; Yemelyanova, A.; Seidman, J.D.; Ronnett, B.M. Cytokeratins 7 and 20 in primary and secondary mucinous tumors of the ovary: Analysis of coordinate immunohistochemical expression profiles and staining distribution in 179 cases. Am. J. Surg. Pathol. 2006, 30, 1130-1139. [CrossRef] [PubMed]

66. Vang, R.; Gown, A.M.; Wu, L.S.; Barry, T.S.; Wheeler, D.T.; Yemelyanova, A.; Seidman, J.D.; Ronnett, B.M. Immunohistochemical expression of CDX2 in primary ovarian mucinous tumors and metastatic mucinous carcinomas involving the ovary: Comparison with CK20 and correlation with coordinate expression of CK7. Mod. Pathol. 2006, 19, 1421-1428. [CrossRef] [PubMed]

67. Hanski, C.; Hofmeier, M.; Schmitt-Gräff, A.; Riede, E.; Hanski, M.L.; Borchard, F.; Sieber, E.; Niedobitek, F.; Foss, H.D.; Stein, H.; et al. Overexpression or ectopic expression of MUC2 is the common property of mucinous carcinomas of the colon, pancreas, breast, and ovary. J. Pathol. 1997, 182, 385-391. [CrossRef]

68. Shin, J.H.; Bae, J.H.; Lee, A.; Jung, C.K.; Yim, H.W.; Park, J.S.; Lee, K.Y. CK7, CK20, CDX2 and MUC2 immunohistochemical staining used to distinguish metastatic colorectal carcinoma involving ovary from primary ovarian mucinous adenocarcinoma. Jpn. J. Clin. Oncol. 2010, 40, 208-213. [CrossRef] [PubMed]

69. Hernandez, B.Y.; Frierson, H.F.; Moskaluk, C.A.; Li, Y.J.; Clegg, L.; Cote, T.R.; McCusker, M.E.; Hankey, B.F.; Edwards, B.K.; Goodman, M.T. CK20 and CK7 protein expression in colorectal cancer: Demonstration of the utility of a population-based tissue microarray. Hum. Pathol. 2005, 36, 275-281. [CrossRef] [PubMed]

70. Baba, Y.; Nosho, K.; Shima, K.; Freed, E.; Irahara, N.; Philips, J.; Meyerhardt, J.A.; Hornick, J.L.; Shivdasani, R.A.; Fuchs, C.S.; et al. Relationship of CDX2 loss with molecular features and prognosis in colorectal cancer. Clin. Cancer Res. 2009, 15, 4665-4673. [CrossRef]

71. Park, S.Y.; Lee, H.S.; Choe, G.; Chung, J.H.; Kim, W.H. Clinicopathological characteristics, microsatellite instability, and expression of mucin core proteins and p53 in colorectal mucinous adenocarcinomas in relation to location. Virchows Arch. 2006, 449, 40-47. [CrossRef] [PubMed]

72. Ishizu, H.; Kumagai, J.; Eishi, Y.; Takizawa, T.; Koike, M. Mucin core protein expression by colorectal mucinous carcinomas with or without mucus hyperplasia. J. Gastroenterol. 2004, 39, 125-132. [CrossRef] [PubMed]

73. Losi, L.; Scarselli, A.; Benatti, P.; Ponz de Leon, M.; Roncucci, L.; Pedroni, M.; Borghi, F.; Lamberti, I.; Rossi, G.; Marino, M.; et al. Relationship between MUC5AC and altered expression of MLH1 protein in mucinous and non-mucinous colorectal carcinomas. Pathol. Res. Pract. 2004, 200, 371-377. [CrossRef] [PubMed]

74. Hess, V.; A'Hern, R.; Nasiri, N.; King, D.M.; Blake, P.R.; Barton, D.P.; Shepherd, J.H.; Ind, T.; Bridges, J.; Harrington, K.; et al. Mucinous epithelial ovarian cancer: A separate entity requiring specific treatment. J. Clin. Oncol. 2004, 22, 1040-1044. [CrossRef] [PubMed]

75. Bamias, A.; Psaltopoulou, T.; Sotiropoulou, M.; Haidopoulos, D.; Lianos, E.; Bournakis, E.; Papadimitriou, C.; Rodolakis, A.; Vlahos, G.; Dimopoulos, M.A. Mucinous but not clear cell histology is associated with inferior survival in patients with advanced stage ovarian carcinoma treated with platinum-paclitaxel chemotherapy. Cancer 2010, 116, 1462-1468. [CrossRef]

76. Pectasides, D.; Fountzilas, G.; Aravantinos, G.; Kalofonos, H.P.; Efstathiou, E.; Salamalekis, E.; Farmakis, D.; Skarlos, D.; Briasoulis, E.; Economopoulos, T.; et al. Advanced stage mucinous epithelial ovarian cancer: The Hellenic Cooperative Oncology Group experience. Gynecol. Oncol. 2005, 97, 436-441. [CrossRef] [PubMed]

77. Pisano, C.; Greggi, S.; Tambaro, R.; Losito, S.; Iodice, F.; Di Maio, M.; Ferrari, E.; Falanga, M.; Formato, R.; Iaffaioli, V.R.; et al. Activity of chemotherapy in mucinous epithelial ovarian cancer: A retrospective study. Anticancer Res. 2005, 25, 3501-3505.

78. Takatori, E.; Shoji, T.; Suga, Y.; Niinuma, H.; Miura, Y.; Kaido, Y.; Takada, A.; Kagabu, M.; Takeuchi, S.; Sugiyama, T. A pilot study of oxaliplatin with oral S-1 as second-line chemotherapy for patients with recurrent adenocarcimona of the uterine cervix. Int. J. Clin. Oncol. 2014, 19, 336-340. [CrossRef] [PubMed] 
79. Huehls, A.M.; Wagner, J.M.; Huntoon, C.J.; Gengm, L.; Erlichman, C.; Patel, A.G.; Kaufmann, S.H.; Karnitz, L.M. Poly (ADPRibose) polymerase inhibition synergizes with 5-fluorodeoxyuridine but not 5-fluorouracil in ovarian cancer cells. Cancer Res. 2011, 71, 4944-4954. [CrossRef] [PubMed]

80. Sato, S.; Itamochi, H.; Kigawa, J.; Oishi, T.; Shimada, M.; Sato, S.; Naniwa, J.; Uegaki, K.; Nonaka, M.; Terakawa, N. Combination chemotherapy of oxaliplatin and 5-fluorouracil may be an effective regimen for mucinous adenocarcinoma of the ovary: A potential treatment strategy. Cancer Sci. 2009, 100, 546-551. [CrossRef]

81. Kurnit, K.C.; Sinno, A.K.; Fellman, B.M.; Varghese, A.; Stone, R.; Sood, A.K.; Gershenson, D.M.; Schmeler, K.M.; Malpica, A.; Fader, A.N.; et al. Effects of Gastrointestinal-Type Chemotherapy in Women with Ovarian Mucinous Carcinoma. Obstet. Gynecol. 2019, 134, 1253-1259. [CrossRef] [PubMed]

82. Gore, M.; Hackshaw, A.; Brady, W.E.; Penson, R.T.; Zaino, R.; McCluggage, W.G.; Ganesan, R.; Wilkinson, N.; Perren, T.; Montes, A.; et al. An international, phase III randomized trial in patients with mucinous epithelial ovarian cancer (mEOC/GOG 0241) with long-term follow-up: And experience of conducting a clinical trial in a rare gynecological tumor. Gynecol. Oncol. 2019, 153, 541-548. [CrossRef]

83. Nishio, S.; Shimada, M.; Kamura, T.; Ishitani, K.; Ochiai, K.; Takeshima, N.; Yokoyama, Y.; Furumoto, H.; Sugiyama, T.; Kigawa, J. Phase II study of combination chemotherapy with oral S-1 and oxaliplatin (SOX) in patients with mucinous adenocarcinoma of the ovary. Ann. Oncol. 2012, 23, ix326. [CrossRef]

84. Jain, A.; Ryan, P.D.; Seiden, M.V. Metastatic mucinous ovarian cancer and treatment decisions based on histology and molecular markers rather than the primary location. J. Natl. Compr. Canc. Netw. 2012, 10, 1076-1080. [CrossRef] [PubMed]

85. Sato, N.; Saga, Y.; Mizukami, H.; Wang, D.; Fujiwara, H.; Takei, Y.; Machida, S.; Ozawa, K.; Suzuki, M. Cetuximab inhibits the growth of mucinous ovarian carcinoma tumor cells lacking KRAS gene mutations. Oncol. Rep. 2012, 27, 1336-1340. [PubMed]

86. Inaba, K.; Oda, K.; Aoki, K.; Sone, K.; Ikeda, Y.; Miyasaka, A.; Kashiyama, T.; Fukuda, T.; Makii, C.; Arimoto, T.; et al. Synergistic antitumor effects of combination PI3K/mTOR and MEK inhibition (SAR245409 and pimasertib) in mucinous ovarian carcinoma cells by fluorescence resonance energy transfer imaging. Oncotarget 2016, 7, 29577-29591. [CrossRef]

87. Spreafico, A.; Oza, A.M.; Clarke, B.A.; Mackay, H.J.; Shaw, P.; Butler, M.; Dhani, N.C.; Lheureux, S.; Wilson, M.K.; Welch, S.; et al. Genotype-matched treatment for patients with advanced type I epithelial ovarian cancer (EOC). Gynecol. Oncol. 2017, 144, 250-255. [CrossRef] [PubMed] 